\title{
Zoonotic Influenza and Human Health-Part 1: Virology and Epidemiology of Zoonotic Influenzas
}

\author{
L. W. Goneau ${ }^{1,2} \cdot$ K. Mehta ${ }^{3} \cdot$ J. Wong ${ }^{3,4,5} \cdot$ A. G. L'Huillier ${ }^{3}$ - J. B. Gubbay ${ }^{1,2,3}$ \\ Published online: 1 August 2018 \\ (C) Springer Science+Business Media, LLC, part of Springer Nature 2018
}

\begin{abstract}
Purpose of Review Zoonotic influenza viruses are those that cross the animal-human barrier and can cause disease in humans, manifesting from minor respiratory illnesses to multiorgan dysfunction. They have also been implicated in the causation of deadly pandemics in recent history. The increasing incidence of infections caused by these viruses worldwide has necessitated focused attention to improve both diagnostic as well as treatment modalities. In this first part of a two-part review, we describe the structure of zoonotic influenza viruses, the relationship between mutation and pandemic capacity, pathogenesis of infection, and also discuss history and epidemiology.

Recent Findings We are currently witnessing the fifth and the largest wave of the avian influenza A(H7N9) epidemic. Also in circulation are a number of other zoonotic influenza viruses, including avian influenza $\mathrm{A}(\mathrm{H} 5 \mathrm{~N} 1)$ and $\mathrm{A}(\mathrm{H} 5 \mathrm{~N} 6)$; avian influenza $\mathrm{A}(\mathrm{H} 7 \mathrm{~N} 2)$; and swine influenza $\mathrm{A}(\mathrm{H} 1 \mathrm{~N} 1) \mathrm{v}, \mathrm{A}(\mathrm{H} 1 \mathrm{~N} 2) \mathrm{v}$, and $\mathrm{A}(\mathrm{H} 3 \mathrm{~N} 2) \mathrm{v}$ viruses. Most recently, the first human case of avian influenza $\mathrm{A}(\mathrm{H} 7 \mathrm{~N} 4)$ infection has been documented.

Summary By understanding the virology and epidemiology of emerging zoonotic influenzas, we are better prepared to face a new pandemic. However, continued effort is warranted to build on this knowledge in order to efficiently combat the constant threat posed by the zoonotic influenza viruses.
\end{abstract}

Keywords Zoonotic influenza $\cdot$ Avian influenza $\cdot$ Swine influenza $\cdot$ Pandemic

\section{Introduction}

Zoonoses are diseases of animals that are transmitted to human beings. These have been present in the human population for thousands of years [1] and have been implicated in several

This article is part of the Topical Collection on Tropical, Travel and Emerging Infections

J. B. Gubbay

jonathan.gubbay@oahpp.ca

1 Public Health Ontario Laboratory, 661 University Avenue, Suite 1701, Toronto, ON M5G 1M1, Canada

2 University of Toronto, 27 King's College Circle, Toronto, ON M5S 1A1, Canada

3 Division of Infectious Diseases, Department of Paediatrics, The Hospital for Sick Children, Toronto, ON, Canada

4 Department of Paediatrics, University of Toronto, Toronto, ON, Canada

5 Department of Paediatrics, North York General Hospital, Toronto, ON, Canada deadly pandemics in the past. Among the zoonoses, influenza A virus is unique in that there exist in nature a multitude of subtypes capable of infecting a wide variety of avian and other animal species as well as humans. Zoonotic influenza viruses are distinct from human seasonal influenza viruses and often do not readily transmit between humans but may occasionally infect humans through direct or indirect contact. Illness caused by these viruses can range from a mild illness to severe infection resulting in death. Examples of zoonotic influenza viruses that have recently caused human infections include several avian influenza, including $\mathrm{A}(\mathrm{H} 7 \mathrm{~N} 9), \mathrm{A}(\mathrm{H} 5 \mathrm{~N} 1), \mathrm{A}(\mathrm{H} 9 \mathrm{~N} 2)$, $\mathrm{A}(\mathrm{H} 5 \mathrm{~N} 6), \mathrm{A}(\mathrm{H} 7 \mathrm{~N} 2)$, and $\mathrm{A}(\mathrm{H} 7 \mathrm{~N} 4)$; and swine influenza variants $\mathrm{A}(\mathrm{H} 1 \mathrm{~N} 1) \mathrm{v}, \mathrm{A}(\mathrm{H} 1 \mathrm{~N} 2) \mathrm{v}$, and $\mathrm{A}(\mathrm{H} 3 \mathrm{~N} 2) \mathrm{v}[2,3 \bullet \bullet$. The genetic plasticity and adaptation in a wide variety of animal and human hosts continue to fuel the emergence of novel strains that can infect humans with increasing efficiency, resulting in widespread pandemics [4]. There were three influenza pandemics in the twentieth century, the deadly Spanish H1N1 1918 pandemic, which affected an estimated one third of the human population, killing an estimated 500 million persons, and the subsequent less severe pandemics of 1957 (H2N2 
virus) and 1968 (H3N2 virus) [5••]. More recently, in 2009, a swine-derived H1N1 influenza A reassortment virus, A(H1N1)pdm09, caused a moderately mild pandemic.

Currently, the world is witnessing the fifth and the most severe wave of the avian influenza $\mathrm{A}(\mathrm{H} 7 \mathrm{~N} 9)$ epidemic. Recurrent outbreaks of infectious diseases originating in animals have been attributed to population explosion in cities with urbanization, overcrowding, domestication of animals, unsanitary living conditions, and increasing travel [1]. In order to prepare for the future and to prevent and contain potential pandemics, it is important to learn from past events and also further analyze recent occurrences of influenza activity, including epizootic outbreaks. In this first part of a two part review titled Zoonotic Influenza and human health, we describe the structure of zoonotic influenza viruses, the relationship between mutation and pandemic capacity, pathogenesis of infection, and also discuss history and epidemiology.

\section{Influenza Structure and Effect on Pathogenesis}

\section{Virology of Influenza Viruses}

Influenza virus belongs to the family Orthomyxoviridae whose members are encoded by a negative-sense, singlestranded RNA genome encapsulated in a proteinaceous nucleocapsid and enveloped in a host-derived lipid membrane. There are three major types of influenza viruses (A, $B$, and C) and a recently described fourth type (D). Influenza A circulates in a wide variety of animals including humans, swine, wild birds, horses, cats, dogs, and others. While humans are the natural host for influenza $\mathrm{B}$, animals such as seals can also be infected. Influenza $\mathrm{C}$ infects both humans and pigs, but infections are generally mild and rarely reported. Influenza D is newly described and is associated primarily with a cattle reservoir and has not been linked to human infection [6]. The genome of influenza is segmented, with the number of segments and genes varying between types. Influenza type A possesses eight segments encoding 10 proteins [polymerase basic 1 and 2 (PB2, PB1), polymerase acidic protein (PA), haemagglutinin (HA), neuraminidase (NA), matrix 1 and 2 (M1, M2), non-structural protein 1 and 2 (NS1, NS2), nuclear export protein (NEP)], while influenzas B and $\mathrm{C}$ possess eight and seven gene segments, respectively, encoding 11 and nine proteins, respectively. The remainder of this review will focus on influenza A virus (IAV) due to its role as an important zoonotic pathogen and its pandemic potential in both humans and animals.

\section{Evolution of Influenza Viruses and Emergence of Novel Strains}

Most zoonotic IAVs are restricted in their ability to replicate in humans [7], and there are many genetic factors that contribute to defining the virulence, transmissibility, host range, and pandemic potential. IAV express an error-prone RNA polymerase which lacks proof-reading activity and postreplicative repair properties, facilitating the rapid accumulation of mutations subject to negative and positive selection which is host-dependent. This process, referred to as genetic drift, results in the production of unique viral progeny at both the individual host and population levels. At the host level, viral quasispecies are produced over the course of infection with multiple strains transmitted simultaneously to new hosts, each with unique fitness advantages and disadvantages potentially contributing to adaptation and crossing of the species barrier $\left[8,9,10^{\bullet}\right]$. Ultra-deep sequencing studies now suggest that human-adaptive mutations in animal-associated IAV can randomly accumulate at low levels in viral quasispecies and circulate within animal populations, to then rapidly expand upon transmission to a human host $[11,12]$. Thus, the risk of zoonotic influenzas that effectively spread in human populations is greatest during outbreaks in animal populations when the overall number of infected animals and therefore genetic variants potentially carrying human-adaptive traits is very high [10॰].

Another source of genetic diversity is the "swapping" of virus genomic segments between IAV strains. This occurs when a single host cell is infected with at least two distinct strains of IAV, resulting in the reassortment of genomic segments into novel viral progeny that are distinct from either parental strain. Genomic reassortment is also referred to as genetic shift and is one of the most important factors contributing to zoonotic IAVs jumping the species barrier. Introduction of animal HA subtypes that are poorly recognized by neutralizing antibodies of the human immune system is a major driving force for pandemics [1, 4]. The 1918 pandemic either arose from direct transmission of an avian influenza virus to humans following genetic drift, or as a result of reassortment. All subsequent pandemics have been the result of the emergence of IAV reassortants (Fig. 1) [13]. Reassortment can arise from the exchange from a single genetic segment, or the swapping of multiple segments; however, a fitness cost may be associated with the simultaneous exchange of multiple segments [14].

\section{Emergence of Avian Influenza A Viruses in Humans-H7N4, H7N9, H5N1, H5N6, H9N2, and H10N8 Subtypes}

The emergence of novel avian IAV continues to threaten the human population. For examples, a newly described 


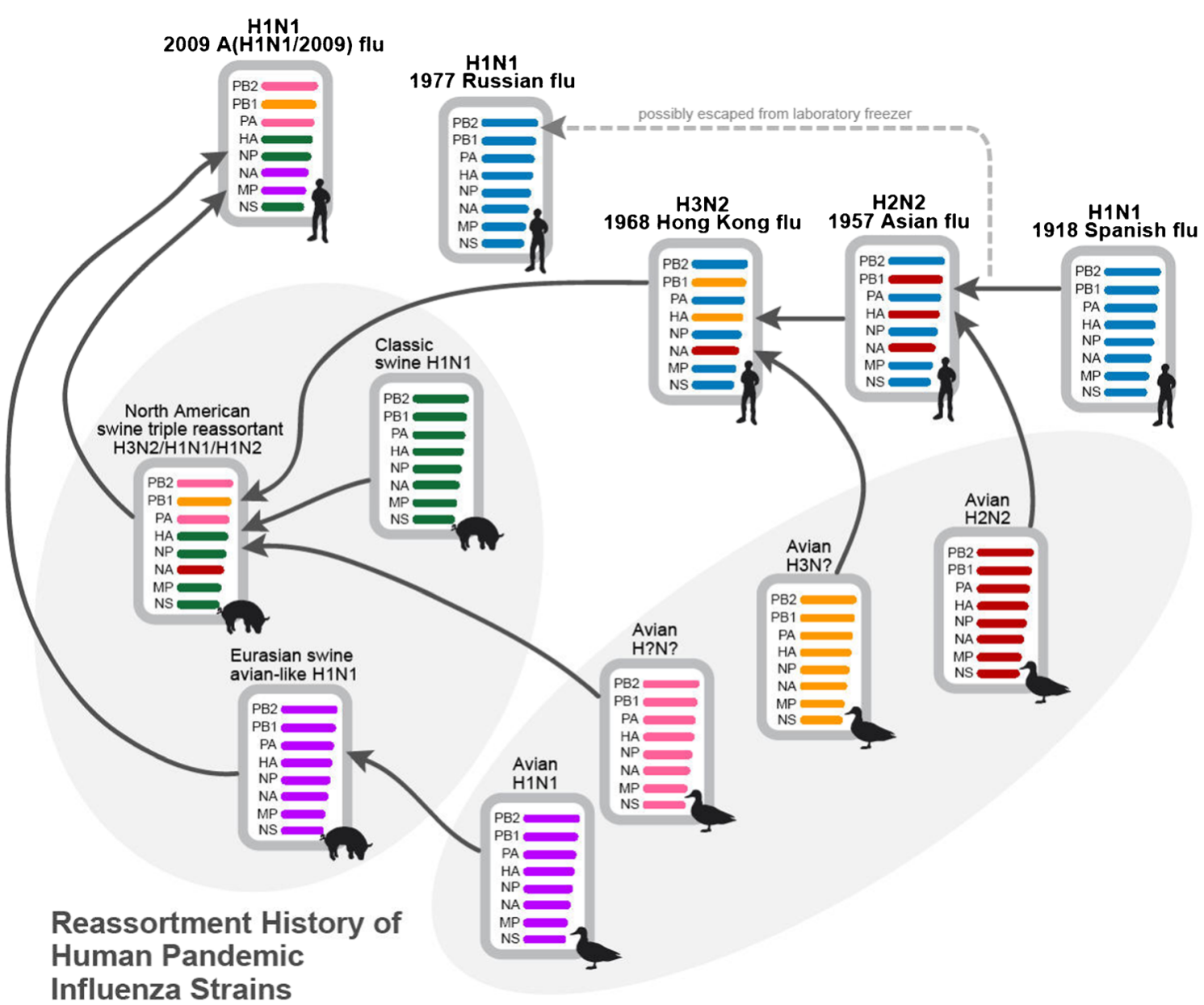

Fig. 1 Schematic diagram showing the reassortment history of human pandemic influenza strains. Each influenza gene segment is represented by a colored, horizontal bar. The reassortment events generating the

H3N2 Hong Kong flu pandemic strain have been simplified here due to space constraints (figure reproduced with permission from Tang et al. [13]) avian IAV variant, H7N4, was recently identified in a 68 year-old patient from China in February of 2018 (WHO Disease Outbreak News). Avian H7N4, H7N9, H5N1, H5N6, H9N2, and H10N8 viruses are all the product of reassortment between IAVs of avian origin. Specifically, $\mathrm{H} 7 \mathrm{~N} 9$ possesses the $\mathrm{H} 7$ gene from $\mathrm{A} /$ duck/Zhejiang/12/ 2011 (H7N3) virus, and the N9 of A/wild bird/Korea/ A14/2011 virus (H7N9) [15, 16••] (Fig. 2). Internal genes cluster together with $\mathrm{H} 9 \mathrm{~N} 2$ viruses isolated from poultry and ducks in China. This is a common feature among emergent avian IAVs, with H5N1, H7N9, H5N6, and $\mathrm{H} 10 \mathrm{~N} 8$ viruses all sharing at least some internal genes originating from $\mathrm{H} 9 \mathrm{~N} 2$ virus $[3 \bullet, 17-21,22 \bullet$, 23]. The $\mathrm{H} 5 \mathrm{~N} 1$ virus specifically possesses the $\mathrm{PB} 2$ gene from $\mathrm{H} 9 \mathrm{~N} 2$ virus [24], while $\mathrm{H} 10 \mathrm{~N} 8$ possesses all six internal genes from H9N2 [25]. Since the internal genes of H9N2 play an important role in the success of zoonotic IAVs in humans, efforts should be made to monitor the spread of this virus $[26,27]$.

\section{Emergence of Swine Influenza Viruses in Humans-H1N1}

Swine have become a reservoir of $\mathrm{H} 1$ viruses with the potential to cause major respiratory outbreaks or pandemics in humans [28]. Genomic analysis of the H1N1pdm09 virus indicates that it is closely related to common reassortant swine IAVs isolated from North America, Europe, and Asia [29]. The NA (N1) and M gene segments are of Eurasian swine lineage circulating exclusively within this swine population since 1979 but were originally derived from wholly avian influenza virus. The HA (H1), NP, and NS gene segments are of classical swine lineage (H1N2) isolated in North America in the late 1990s [29]. The PA, PB1, and PB2 gene segments are of swine triple-reassortant H3N2 lineage [28]. Antigenically, all A(H1N1)pdm09 isolates were similar to classical swine viruses and the reassortant $\mathrm{H} 1 \mathrm{~N} 1$ viruses that had been circulating among pigs in the USA in the decade prior to emergence in humans, showing no antigenic cross- 
Genetic Evolution of H7N9 Virus in China, 2013

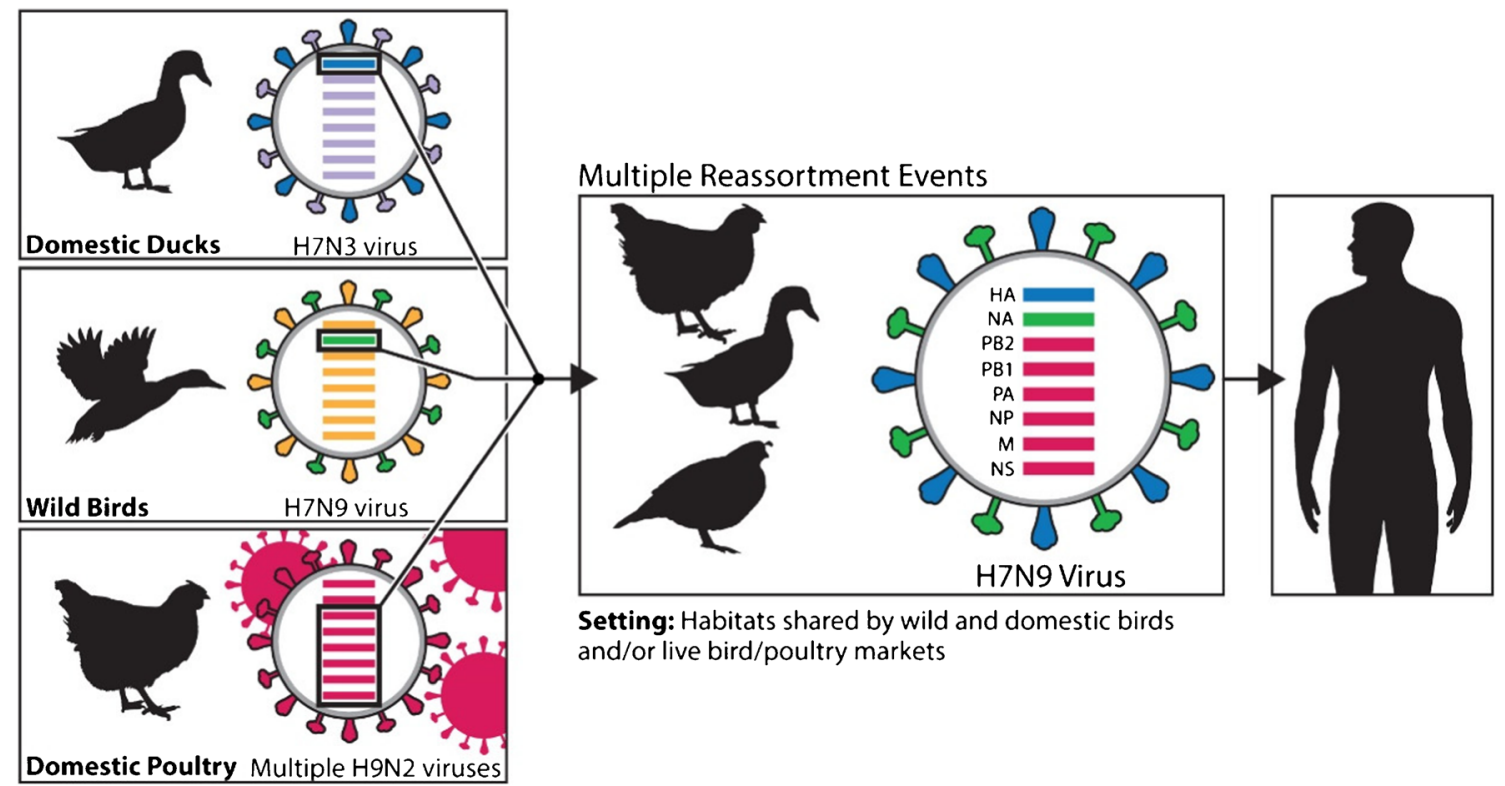

Fig. 2 The eight genes of the H7N9 virus are closely related to avian influenza viruses found in domestic ducks, wild birds, and domestic poultry in Asia. Each influenza gene segment is represented by a colored, horizontal bar. H7N9 virus likely obtained its HA (hemagglutinin) gene from domestic ducks, its NA (neuraminidase)

reactivity with contemporary human seasonal $\mathrm{H} 1 \mathrm{~N} 1$ viruses [30]. Specifically, segments coding for NA and M proteins are distantly related to swine viruses isolated in Europe in the 1990s [29].

\section{Genetic Factors Contributing to Transmissibility and Virulence in Humans}

Several factors affect influenza's transmissibility, virulence, pandemic potential, and ability to cross the species barriers. However, the contribution of HA and NA glycoproteins is best described. There are 18 different HA and 11 different NA IAV subtypes, all of which have different host-receptor specificities and influence on transmission and disease severity. HA is composed of two subunits (HA1 and HA2) and is responsible for binding to host receptors containing glycans with terminal sialic acid (SA) residues. Specifically, HA will preferentially bind residues with either $\alpha 2-3$ or $\alpha 2-6$ branching with respect to their linkage to galactose. Avian strains of IAV preferentially bind $\alpha 2-3$-SA residues, while mammalian viruses prefer $\alpha 2-6-\mathrm{SA}$ residues $[31,32]$. Lectin-staining studies demonstrate that anatomic distribution of SA residues varies between birds and mammals, and also between species within either family. For example, $\alpha 2-3$-SA receptors are located in the lower respiratory tract of humans [specifically, lower respiratory tract (LRT) epithelial cells, bronchi, bronchioles, type II pneumocytes] [33, 34], while the upper respiratory tract (URT) of humans is dominated by gene from wild birds, and its six remaining internal genes from multiple related H9N2 influenza viruses in domestic poultry (figure reproduced with permission from the Centers for Disease Control and Prevention $[16 \bullet \cdot])$

$\alpha 2-6-$ SA residues. However, swine expresses both $\alpha 2-6$ - and $\alpha 2-3$-SA residues throughout their upper and lower respiratory tracts [35-37]. Evidence suggests that the affinity of HA for SA receptors influences the transmissibility and virulence properties of IAV. For example, preference for $\alpha 2-6$ receptors facilitates spread, while preference for $\alpha 2-3$ receptors (and thus enhanced tropism for the LRT) influences disease severity in humans [38]. While wild aquatic birds possess primarily $\alpha 2-3-S A$ receptors in their intestinal and respiratory tracts, gallinaceous poultry species (domestic poultry and game birds, for example quail, chickens, turkeys) can carry both $\alpha 2-3$ - and $\alpha 2-6-$ SAs throughout both their intestinal and respiratory tracts [34]. Therefore, the potential exists that adaptive mutations in domesticated poultry could shift HA preference from wild aquatic birds to human-like SA receptors [10•]. Evidence supports this hypothesis, with strains of H9N2 [39, 40], H5N1 [41, 42], and H7 subtypes [43, 44] isolated from poultry possessing an increased specificity for human $\alpha 2-6-$ SA residues. SA receptor-binding domain (RBD) changes in HA can lead to differences in preferential binding between $\alpha 2-3$ - and $\alpha 2-6$-linked residues, and therefore changes in host-range and disease severity. Kilander et al. (2010) observed an association between HA1 mutation D222G in the 2009 pandemic IAV A(H1N1) and severe clinical outcomes in humans [45]. It was then shown that this mutation influenced receptor binding, bestowing dual receptor specificity for both $\alpha 2-3$ and $\alpha 2-6$ types [46]. Other mutations, including the well-described G226L mutation in $\mathrm{H} 7 \mathrm{~N} 9$, 
permit more effective binding of HA to human-like SAs [47-54]. Although these adaptations are of concern, an H5N1 or H7N9 IAV with preferential binding of humantype-SA-receptors compared to avian-type SA receptors has yet to be observed. Other avian IAVs that have not undergone such human-adaptation have HAs that interact poorly with $\alpha 2-6$-linked residues and preferentially bind to bird-type $\alpha 2-3-$ SA [55]. However, it is hypothesized that these IAVs will too increase their specificity for human-type receptors over time. Changes to N-linked glycosylation and the presence of multi-basic cleavage sites resulting in the production of modified HA have also been described to influence receptor binding and virulence in mice [56-58]. However, often, these findings in animal-adapted IAV do not translate to altered virulence in human strains [59-61]. These features of zoonotic IAVs have recently been reviewed elsewhere [62].

The NA enzyme is composed of an enzymatically active head, a transmembrane region embedded in the virus membrane associated with a highly conserved cytoplasmic tail, and a stalk region which connects these head and transmembrane regions. The purpose of NA is to cleave SA residues as an important step in viral budding and release from cells. The balance between HA binding and NA cleavage of SA residues is essential for effective virus replication and varies from hostto-host [63]. Thus, factors that affect NA activity will impact virus replication. For example, stalk length appears to impact infectivity in humans, gallinaceous birds, and aquatic birds differently. Specifically, short stalks are more frequently associated with gallinaceous birds and humans, while longer stalks are more common in aquatic birds such as ducks [64-66]. The variability in stalk length is dependent on mutations which result in deletions in the stalk region [67]. Other mutations in NA have been associated with a fatal human case of Avian influenza A H7N7 [68]. It is thought that the changes observed in NA prevented the formation of viral aggregates which improved replication efficiency in the human respiratory tract [44]. However, stalk length and other changes to NA are not sufficient to dictate disease severity in all IAVs. For example, an H1N1pdm09 expressing short-stalk NA from an H5N1 derived from adaptation in chickens replicated poorly in human respiratory cells and did not transmit efficiently by respiratory droplet between ferrets [69].

The combination of zoonotic IAV surface glycoproteins with core human virus replicative genes creates novel viruses that could bind human respiratory tract mucosa while replicating more efficiently than either parent strain [70]. Therefore, hosts that are conducive for transmission and efficient replication of both zoonotic and human virus pose the greatest risk for the development of novel reassortments that will efficiently replicate in humans. Swine, which contain both $\alpha 2-3$ and $\alpha 2-6$ receptors, are examples of such hosts and have historically been described as "mixing vessels" for the emergence of novel reassortant IAV strains [71]. Interestingly, recent evidence suggests that turkeys and quail may play just as important a role in avian influenza human adaptation as swine do, due to the presence of both receptors in these species and the described accumulation of adaptive mutations for effective transmission in gallinaceous birds [72-75]. Experimental coinfection models using quails as mixing vessels has provided supporting evidence for this hypothesis, as this practice has resulted in the production of several zoonotic-human reassortant viruses [76].

Although the role of HA and NA is well-established, changes in these genes through reassortment and the accumulation of adaptive mutations are not always sufficient to permit efficient transmission in humans [77]. For example, although H9N2 has an increased preference for $\alpha 2-6$-SA receptors compared to other IAVs, it has caused predominantly caused mild disease in few humans $[3 \cdot \bullet, 78]$. Furthermore, it has been established that some zoonotic influenza components are incompatible with human viruses. For example, some avian HA types and human IAV matrix protein combinations result in the production of attenuated virus $[79,80]$. In ferret models of infection, several successive adaptive mutations in a number of genes are required to permit effective ferret-to-ferret transmission via the aerosol and airborne routes [81-83]. Poor transmissibility and mild disease associated with many zoonotic IAVs despite the presence of human-adaptive HA can partially be explained by the presence of inefficient animal IAV polymerase complexes with decreased replicative capacity in humans [84]. This limitation can be overcome by adaptive mutations, primarily in the PB2 region of the polymerase enzyme [85-87]. Several adaptive mutations in the polymerase complex of $\mathrm{H} 5 \mathrm{~N} 1$ have been identified as contributing to more effective replication in mammals [44, 88]. Conversely, most zoonotic H7N9 viruses that have been isolated from humans carry unique mutations in their polymerase PB2 enzyme that are absent from strains isolated from birds [19-21]. However, several adaptive mutations in PB1, PA, NP, and NEP have been described that are able to compensate for the poor polymerase activity of zoonotic IAVs in human cells [89]. A real-world example of this can be found in the recent swine origin $\mathrm{H} 3 \mathrm{~N} 2$ quadruple reassortant IAV which possessed a novel $\mathrm{M}$ protein from a Eurasian swine IAV lineage [90]. The $M$ segment in this new strain, derived from the 2009 pandemic H1N1 (H1N1pdm09) virus, has been shown to increase NA activity, resulting in more efficient transmission in humans [91-93] (Fig. 3).

\section{Epidemiology}

\section{Avian Influenza A(H5N1)}

H5N1 viruses were first recognized in humans in 1997 in Hong Kong and have resulted in a substantial number of human cases since [94]. Genotyping of the novel virus revealed 


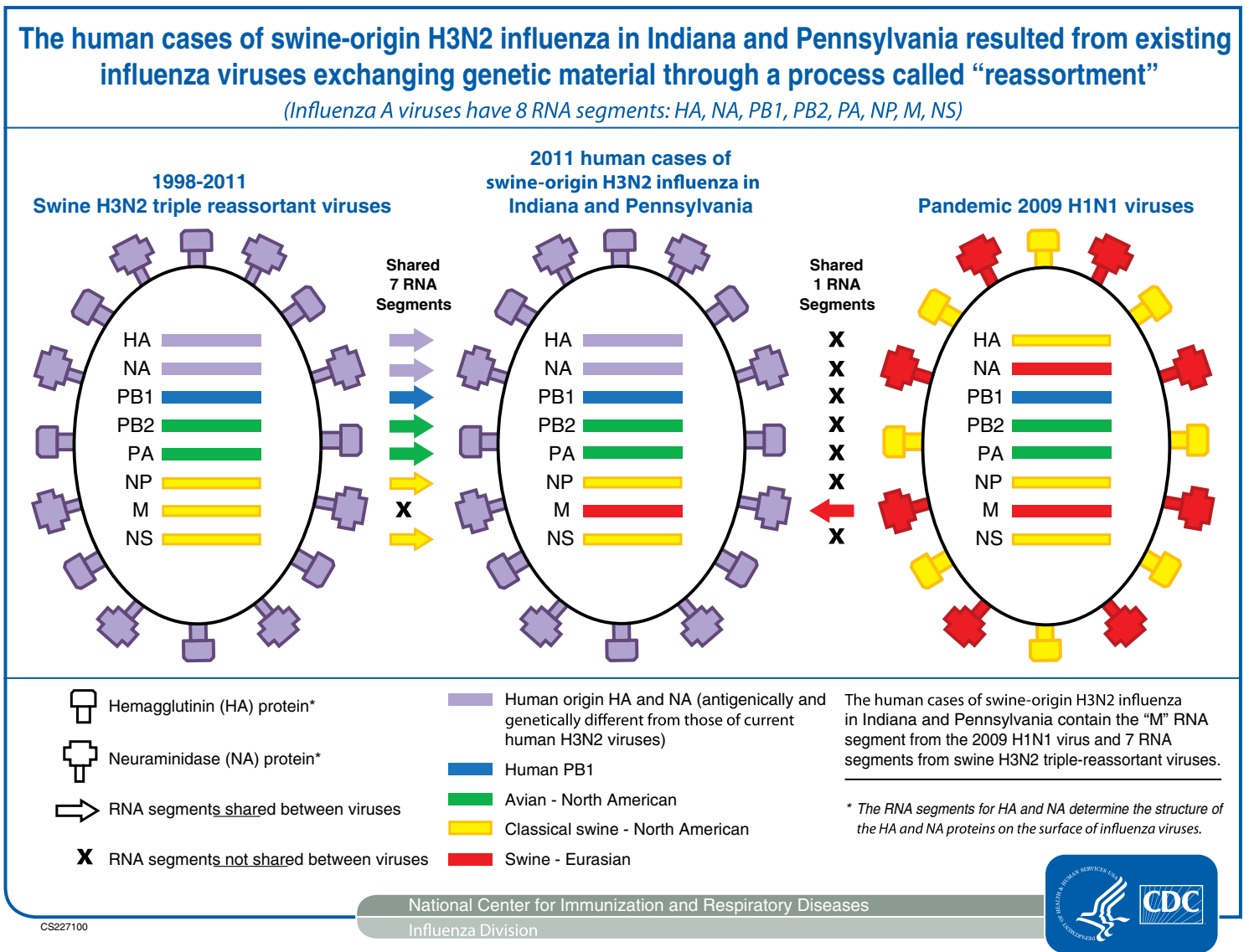

Fig. 3 Schematic diagram showing an example of genetic reassortment resulting in the production of novel swine-origin $\mathrm{H} 3 \mathrm{~N} 2$ virus isolated in 2011 in Indiana and Pennsylvania, USA. This virus represents a mixture of different gene segments from both H3N2 (left virion) and pandemic $2009 \mathrm{H} 1 \mathrm{~N} 1$ (right virion). This novel influenza represents a

that all genes were of avian origin, suggestive of the fact that H5N1 had jumped the species barrier without adaptation [95]. In 2003, H5N1 re-emerged in humans when two cultureconfirmed cases were detected in a family group returning to Hong Kong from China [96]. As of October 30, 2017, a total of 860 laboratory-confirmed cases of human infection with avian influenza $\mathrm{A}(\mathrm{H} 5 \mathrm{~N} 1)$ virus, including 454 deaths, had been reported since 2003 to WHO from 16 countries [97]. Human H5N1 infections have been confirmed in Azerbaijan, Bangladesh, Cambodia, Canada, China, Djibouti, Egypt, Indonesia, Iraq, Laos, Myanmar, Nigeria, Pakistan, Thailand, Turkey, and Vietnam [97]. The largest number of annual reported human cases so far has been from Egypt in the year 2015, during which 136 cases were reported [98]; an epidemiological linkage of human contact with extensive household and farm poultry infections and no evidence of human-to-human transmission were noted in that year in Egypt. The H5N1 viruses are currently classified into 10 clades (clades 0 to 9), of which viruses in clade $0,1,2$, and 7 have been responsible for disease in humans [99]. The viruses from human cases during 2015 to 2017 that have been predominantly swine-origin H3N2 core genome, with pandemic 2009 H1N1 M gene of Eurasian swine linage (indicated by red arrow; figure reproduced with permission from the Centers for Disease Control and Prevention [93])

characterized from Egypt belong to genetic clade 2.2.1.2, and those from Bangladesh belong to clade 2.3.2.1a [3••].

\section{Avian Influenza A(H7N9)}

On March 30, 2013, three patients from China with fatal cases of rapid, progressive pneumonia were confirmed to be infected with a novel avian-origin influenza $\mathrm{A}(\mathrm{H} 7 \mathrm{~N} 9)$ virus that had not been detected or described in humans and animals previously $[15,100]$. The initial wave of avian influenza in humans occurred in the spring of 2013, between February and May 2013, during which a total of 133 cases were reported [101]. Thereafter, cases have been described in waves each year, coinciding with influenza season, with most cases occurring between December and May. Thus far, five waves of outbreaks of H7N9 in humans have been described, with the fifth, from late 2016 to 2017 , the largest to date. As of September 13, 2017, the WHO has reported 764 human infections with Asian H7N9 virus during the fifth epidemic [97], which is more cases than observed in the previous four waves combined, during which 135, 320, 224, and 119 cases 
were reported to WHO [3••]. Among all influenza viruses assessed using CDC's Influenza Risk Assessment Tool (IRAT), the Asian lineage avian influenza A(H7N9) virus is ranked as the influenza virus with the highest potential pandemic risk [102].

\section{Other Avian Influenzas}

As of August 2017, avian influenza H5N6 viruses has been isolated from 16 individuals in China since 2014 when first detected [3••, 103•, 104]. Influenza H9N2 viruses have been isolated mainly from children with mild, self-limited respiratory infection in southern China including Hong Kong, Bangladesh, and Egypt [105]. Avian influenza H7 viruses have also been linked to occasional human disease. Extensive outbreaks of H7N7 occurred among poultry in the Netherlands in 2003 [106]. Additional influenza H7 conjunctival and/or respiratory infections have been reported from Canada, the USA, Italy, and the UK among poultry workers [68]. Among other avian influenza viruses, the first known human case of avian influenza A H6N1 was reported from Taiwan in May 2013 [107]. The first human infection with avian influenza H10N8 was detected in China in a 73-year-old woman in December 2013 [25], and another case from China has also been reported [108]. Mild human infections with avian influenza A H10N7 have been reported previously in Egypt and Australia [108]. Although the overall public health risk from currently known influenza viruses at the humananimal interface has not changed, the likelihood of sustained human-to-human transmission of these viruses remains low. Further human infections with viruses of animal origin are expected [97].

\section{Avian Influenza and Pandemics of the Twentieth Century}

The 1918 influenza pandemic (Spanish Influenza) was the most severe pandemic in recent history. It was caused by an H1N1 virus with genes of avian origin. It is estimated that about 500 million people or one third of the world's population became infected with this virus. The number of deaths was estimated to be at least 50 million worldwide. The high mortality in healthy people, including those in the 20-40 year age group, was a unique feature of this pandemic, which was unprecedented before and since $[109,110]$. Thereafter, in February 1957, a new influenza A(H2N2) virus emerged in East Asia (Asian Influenza), and it caused an estimated number of 1.1 million deaths worldwide. This $\mathrm{H} 2 \mathrm{~N} 2$ virus was comprised of three different genes from an $\mathrm{H} 2 \mathrm{~N} 2$ virus that originated from an avian influenza $\mathrm{A}$ virus, including the $\mathrm{H} 2$ hemagglutinin and the $\mathrm{N} 2$ neuraminidase genes. The novel HA and NA antigens did not induce cross-reactive proteins from previous influenza A exposure, and hence the population at large was unprotected. Most of the deaths were attributed to primary influenza pneumonia and secondary bacterial infection, with the highest mortality rates observed in the elderly, pregnant women, and those with chronic diseases $[109,110]$. The next pandemic of significance, the 1968 pandemic, was caused by an influenza $\mathrm{A}(\mathrm{H} 3 \mathrm{~N} 2)$ virus. This virus differed from its antecedent Asian virus by its HA antigen but retained the same (N2) NA antigen. It caused an estimated one million deaths worldwide, with most deaths occurring in the elderly population aged 65 and older [110].

\section{Swine Influenza}

Swine are naturally infected by IAVs and influenza $\mathrm{C}$ viruses (ICVs). Recent serologic studies also suggest that they can be infected with influenza B and influenza D viruses [111]. Swine play an important role in the ecology of IAVs because these animals are susceptible to viruses of both avian and mammalian lineages [111]. Pigs and humans have shared IAVs since the illness was first described among pigs in 1918-1919 during the Spanish Flu outbreak $[112,113 \bullet, 114]$. Virologic studies that first isolated influenza virus from pigs were performed by Shope and Lewis in 1930 [115]. This "classical" swine H1N1 remained relatively genetically stable, while it continued to circulate within the swine population, evolving separately from the human H1N1 lineage. Swine H1N1 was subsequently isolated from a human in 1974 [116] and continued to be the isolated strain among over 40 confirmed cases of transmission of IAV from pigs to humans in the USA $[112,117]$. A 1976 outbreak with a novel swine H1N1 influenza virus among soldiers at Fort Dix, NJ, demonstrated person-toperson transmission, unlike the majority of sporadic cases [117]. The epidemiology of IAV in US pigs dramatically changed after 1998 when triple-reassortant H3N2 viruses (containing gene segments from the classical swine virus, H3N2 human seasonal IAV, and avian IAV) became successfully established in the pig population [118]. When humans are infected with IAVs that are known to be genetically similar to viruses circulating in swine, these viruses are called "variant viruses" and denoted with a letter "v." Subsequently, identified strains of swine influenza that were reported to the CDC among human infections from 2005 to 2009 were all caused by triple reassortant H1N1v or H1N2v swine influenza viruses [119].

In 2009, the first pandemic influenza outbreak of the new millennium affected more than 214 countries and was responsible for almost 18,500 deaths [120]. It was caused by an H1N1 strain that was a descendent of the strain that caused the 1918 flu pandemic [113•]. However, the unique combination of gene segments had never before been recognized in swine, and exposure to swine was not a common 
epidemiologic feature among human cases of pandemic influenza [118]. The virus was detected first in Mexico, followed by cases in California and then spread quickly across the world. Human influenza-like illness reports preceded documented swine outbreaks due to H1N1pdm09, and the rapid global appearance of H1N1pdm09 in pigs can be attributed to spread by humans with subsequent propagation between pigs rather than international or domestic movement of pigs [118]. Prior to this pandemic, most zoonotic influenza infections typically occurred infrequently with a sporadic pattern typical of animal to human transmission without sustained human-to-human transmission. The H1N1pdm09 strain was the first swine virus to establish sustained human-to-human transmission. Furthermore, most cases were not associated with close animal contact, unlike the sporadic cases in the past $[112,121 \bullet \cdot]$. The CDC estimated that between 151,700 and 575,400 people worldwide died from 2009 H1N1 virus infection during the first year the virus circulated and that $80 \%$ of (H1N1)pdm09 virusassociated deaths were in people younger than 65 years of age [122].

Following the 2009 pandemic, a recent review of emerging influenza $\mathrm{A}$ infections in humans identified three reassortants that are predominantly zoonotic swine influenza variants [121••]. In late 2009 , a novel $\mathrm{A}(\mathrm{H} 1 \mathrm{~N} 2)$ virus was isolated in India, containing a reassortant of A(H1N1)pdm09 and $\mathrm{A}(\mathrm{H} 3 \mathrm{~N} 2)$ viruses that were co-circulating. In the USA, a number of human infections with swine $\mathrm{H} 3 \mathrm{~N} 2 \mathrm{v}$ viruses were identified in the fall of 2011 [123]. The number of cases of $\mathrm{H} 3 \mathrm{~N} 2 \mathrm{v}$ rose dramatically in the late summer of 2012, to a peak of 300 cases [124]. Subsequently in 2012, swine-origin $\mathrm{A}(\mathrm{H} 1 \mathrm{~N} 2) \mathrm{v}$ viruses were isolated in humans in the USA. These $\mathrm{A}(\mathrm{H} 1 \mathrm{~N} 2) \mathrm{v}$ viruses were reassortants of the triple reassortant $\mathrm{A}(\mathrm{H} 1 \mathrm{~N} 2)$ viruses circulating in US Swine and $\mathrm{A}(\mathrm{H} 1 \mathrm{~N} 1) \mathrm{pdm} 09$ viruses. These cases were linked to the Minnesota state fair, isolated from humans who had been in close contact with swine [125]. There has been sporadic transmission of these newly identified variant influenza viruses since their original identification was largely restricted in the USA and Canada [121••].

Swine influenza virus infections in humans have been reported in the USA, Canada, Europe, and Asia [2, 114]. However, very little epidemiological data is available regarding the spread of these viruses in the African continent [30, 118]. Following the outbreak at Fort Dix in 1976, there was likely heightened awareness and surveillance. Unfortunately, given the significant overlap of clinical disease with seasonal human influenza, likely nonfatal cases of swine influenza continue to occur but are not reported [114]. The higher number of reported cases from the USA, despite China being the largest global producer of swine, highlights likely case ascertainment disparities and stronger animal surveillance systems in the USA $[121 \bullet \cdot]$.

\section{Summary}

In summary, zoonotic influenza viruses that cross the animalhuman divide to infect people are considered novel to humans. These viruses may acquire the ability to transmit efficiently among humans, through mutation, reassortment, or both, and are the source of emerging influenza viruses with pandemic potential; some of these have caused the important pandemics in recent history. Hosts such as swine and gallinaceous poultry that are favorable for transmission and efficient replication of both zoonotic and human viruses can serve as mixing vessels and pose the greatest risk for the development of novel reassortments that can replicate competently in humans.

\section{Compliance with Ethical Standards}

Conflict of Interest The authors declare that they have no conflict of interest.

Human and Animal Rights and Informed Consent This article does not contain any studies with human or animal subjects performed by any of the authors.

\section{References}

Papers of particular interest, published recently, have been highlighted as:

- Of importance

•- Of major importance

1. Prescott J. Man and microbes. Disease and plagues in history and modern times. Can Vet J. 1996;37(7):425.

2. Winter AL, Eshaghi A, Farrell DJ, King A, Li A, Li Y, et al. Variant influenza A (H1N1) virus infection in Canada. J Clin Virol. 2013;57(3):279-81. https://doi.org/10.1016/j.jcv.2013.03. 011.

3.• World Health Organization. Human cases of influenza at the human-animal interface, January 2015 - April 2017. Wkly Epidemiol Rec. 2017;92(33):460-75. Available at http://apps. who.int/iris/bitstream/10665/258733/1/WER9233-460-475.pdf. Accessed December 13, 2017. This reference enlists the total number of recorded cases of human cases of influenza at the human-animal interface.

4. Gething MJ, Bye J, Skehel J, Waterfield M. Cloning and DNA sequence of double-stranded copies of haemagglutinin genes from $\mathrm{H} 2$ and $\mathrm{H} 3$ strains elucidates antigenic shift and drift in human influenza virus. Nature. 1980;287(5780):301-6. http://www.ncbi. nlm.nih.gov/pubmed/7421990. Accessed December 10, 2017

5.• Centers for Disease Control and Prevention. Past pandemics. Available at https://www.cdc.gov/flu/pandemic-resources/basics/ past-pandemics.html. Accessed 2 December 2017. This reference provides useful information regarding previously documented pandemic influenzas.

6. Ducatez MF, Pelletier C, Meyer G. Influenza D virus in cattle, France, 2011-2014. Emerg Infect Dis. 2015;21(2):368-71. https://doi.org/10.3201/eid2102.141449. 
7. Beare AS, Webster RG. Replication of avian influenza viruses in humans. Arch Virol. 1991;119(1-2):37-42. https://doi.org/10. 1007/BF01314321.

8. Hoelzer K, Murcia PR, Baillie GJ, Wood JLN, Metzger SM, Osterrieder $\mathrm{N}$, et al. Intrahost evolutionary dynamics of canine influenza virus in naive and partially immune dogs. J Virol. 2010;84(10):5329-35. https://doi.org/10.1128/JVI.02469-09.

9. Murcia PR, Hughes J, Battista P, et al. Evolution of an Eurasian avian-like influenza virus in naïve and vaccinated pigs. Wilke $\mathrm{CO}$, ed. PLoS Pathog. 2012;8(5):e1002730. doi:https://doi.org/10. 1371/journal.ppat.1002730.

10. Munoz O, De Nardi M, Van Der Meulen K, et al. Genetic adaptation of influenza a viruses in domestic animals and their potential role in interspecies transmission: a literature review. EcoHealth. 2016;13(1):171-98. https://doi.org/10.1007/s10393-014-1004-1. This reference describes the genetic adaptation of influenza $A$ viruses in domestic animals and their potential role in interspecies transmission.

11. Jonges M, Bataille A, Enserink R, Meijer A, Fouchier RAM, Stegeman A, et al. Comparative analysis of avian influenza virus diversity in poultry and humans during a highly pathogenic avian influenza A (H7N7) virus outbreak. J Virol. 2011;85(20):10598604. https://doi.org/10.1128/JVI.05369-11.

12. Jonges M, Welkers MR, Jeeninga RE, et al. Emergence of the virulence-associated PB2 E627K substitution in a fatal human case of highly pathogenic avian influenza virus a(H7N7) infection as determined by Illumina ultra-deep sequencing. J Virol. 2014;88(3):1694-702. https://doi.org/10.1128/JVI.02044-13.

13. Tang JW, Shetty N, Lam TT, Hon KL. Emerging, novel, and known influenza virus infections in humans. Infect Dis Clin N Am. 2010;24(3):603-17. https://doi.org/10.1016/j.idc.2010.04. 001.

14. Villa M, Lässig M. Fitness cost of reassortment in human influenza. Wilke CO, ed. PLoS Pathog. 2017;13(11):e1006685. doi: https://doi.org/10.1371/journal.ppat.1006685.

15. Gao R, Cao B, Hu Y, Feng Z, Wang D, Hu W, et al. Human infection with a novel avian-origin influenza A (H7N9) virus. N Engl J Med. 2013;368(20):1888-97. https://doi.org/10.1056/ NEJMoa1304459.

16.• Centers for Disease Control and Prevention. Asian Lineage Avian Influenza A (H7N9) Virus. Avian Influenza (Flu). Available at https://www.cdc.gov/flu/avianflu/h7n9-virus.htm. Accessed December 12, 2017. This reference provides useful information regarding H7N9 Influenza A virus.

17. Guan Y, Shortridge KF, Krauss S, Webster RG. Molecular characterization of H9N2 influenza viruses: were they the donors of the "internal" genes of H5N1 viruses in Hong Kong? Proc Natl Acad Sci U S A. 1999;96(16):9363-7. https://doi.org/10.1073/ pnas.96.16.9363.

18. Lin YP, Shaw M, Gregory V, Cameron K, Lim W, Klimov A, et al. Avian-to-human transmission of H9N2 subtype influenza A viruses: relationship between H9N2 and H5N1 human isolates. Proc Natl Acad Sci. 2000;97(17):9654-8. https://doi.org/10.1073/pnas. 160270697.

19. Kageyama T, Fujisaki S, Takashita E, Xu H, Yamada S, Uchida Y, et al. Genetic analysis of novel avian a(H7N9) influenza viruses isolated from patients in China, February to April 2013. Euro Surveill. 2013;18(15):20453.

20. Lam TT, Wang J, Shen Y, et al. The genesis and source of the H7N9 influenza viruses causing human infections in China. Nature. 2013;502(7470):241-4. https://doi.org/10.1038/ nature12515.

21. Wang D, Yang L, Gao R, Zhang X, Tan Y, Wu A, et al. Genetic tuning of the novel avian influenza $\mathrm{A}(\mathrm{H} 7 \mathrm{~N} 9)$ virus during interspecies transmission, China, 2013. Eur Secur. 2014;19(25):1-17. https://doi.org/10.2807/1560-7917.ES2014.19.25.20836.
22. Pu J, Wang S, Yin Y, Zhang G, Carter RA, Wang J, et al. Evolution of the H9N2 influenza genotype that facilitated the genesis of the novel H7N9 virus. Proc Natl Acad Sci. 2015;112(2):548-53. https://doi.org/10.1073/pnas.1422456112. This reference traces the genesis of the novel H7N9 virus.

23. Xiao C, Ma W, Sun N, Huang L, Li Y, Zeng Z, et al. PB2-588 v promotes the mammalian adaptation of H10N8, H7N9 and H9N2 avian influenza viruses. Sci Rep. 2016;6(1):19474. https://doi.org/ 10.1038/srep19474.

24. Pabbaraju K, Tellier R, Wong S, Li Y, Bastien N, Tang JW, et al. Full-genome analysis of avian influenza $\mathrm{A}(\mathrm{H} 5 \mathrm{~N} 1)$ virus from human, North America, 2013. Emerg Infect Dis. 2014;20(5):887-91. https://doi.org/10.3201/eid2005.140164.

25. Chen H, Yuan H, Gao R, Zhang J, Wang D, Xiong Y, et al. Clinical and epidemiological characteristics of a fatal case of avian influenza A H10N8 virus infection: a descriptive study. Lancet. 2014;383(9918):714-21. https://doi.org/10.1016/S0140 6736(14)60111-2.

26. Thuy DM, Peacock TP, Bich VT, et al. Prevalence and diversity of H9N2 avian influenza in chickens of Northern Vietnam, 2014. Infect Genet Evol. 2016;44:530-40. https://doi.org/10.1016/j. meegid.2016.06.038.

27. Rahimirad S, Alizadeh A, Alizadeh E, Hosseini SM. The avian influenza H9N2 at avian-human interface: a possible risk for the future pandemics. J Res Med Sci. 2016;21(4):51. https://doi.org/ 10.4103/1735-1995.187253.

28. Garten RJ, Davis CT, Russell CA, Shu B, Lindstrom S, Balish A, et al. Antigenic and genetic characteristics of swine-origin 2009 $\mathrm{A}(\mathrm{H} 1 \mathrm{N1})$ influenza viruses circulating in humans. Science. 2009;325(5937):197-201. https://doi.org/10.1126/science. 1176225 .

29. Trifonov V, Khiabanian H, Rabadan R. Geographic dependence, surveillance, and origins of the 2009 influenza A (H1N1) virus. N Engl J Med. 2009;361(2):115-9. https://doi.org/10.1056/ NEJMp0904572.

30. Girard MP, Tam JS, Assossou OM, Kieny MP. The 2009 A (H1N1) influenza virus pandemic: a review. Vaccine. 2010;28(31):4895-902. https://doi.org/10.1016/J.Vaccine.2010. 05.031 .

31. Connor RJ, Kawaoka Y, Webster RG, Paulson JC. Receptor specificity in human, avian, and equine $\mathrm{H} 2$ and $\mathrm{H} 3$ influenza virus isolates. Virology. 1994;205(1):17-23. https://doi.org/10.1006/ viro.1994.1615.

32. Matrosovich MN, Gambaryan AS, Teneberg S, Piskarev VE, Yamnikova SS, Lvov DK, et al. Avian influenza A viruses differ from human viruses by recognition of sialyloligosaccharides and gangliosides and by a higher conservation of the HA receptorbinding site. Virology. 1997;233(1):224-34. https://doi.org/10. 1006/viro.1997.8580.

33. Shinya K, Ebina M, Yamada S, Ono M, Kasai N, Kawaoka Y. Influenza virus receptors in the human airway. Nature. 2006;440(7083):435-6. https://doi.org/10.1038/440435a.

34. Costa T, Chaves AJ, Valle R, Darji A, van Riel D, Kuiken T, et al. Distribution patterns of influenza virus receptors and viral attachment patterns in the respiratory and intestinal tracts of seven avian species. Vet Res. 2012;43(1):28. https://doi.org/10.1186/12979716-43-28.

35. van Riel D, Munster VJ, de Wit E, Rimmelzwaan GF, Fouchier RAM, Osterhaus ADME, et al. Human and avian influenza viruses target different cells in the lower respiratory tract of humans and other mammals. Am J Pathol. 2007;171(4):1215-23. https://doi. org/10.2353/ajpath.2007.070248.

36. Nelli RK, Kuchipudi SV, White GA, Perez BB, Dunham SP, Chang KC. Comparative distribution of human and avian type sialic acid influenza receptors in the pig. BMC Vet Res. 2010;6(1):4. https://doi.org/10.1186/1746-6148-6-4. 
37. Van Poucke SG, Nicholls JM, Nauwynck HJ, Van Reeth K. Replication of avian, human and swine influenza viruses in porcine respiratory explants and association with sialic acid distribution. Virol J. 2010;7(1):38. https://doi.org/10.1186/ 1743-422X-7-38.

38. Kong W, Liu Q, Sun Y, Wang Y, Gao H, Liu L, et al. Transmission and pathogenicity of novel reassortants derived from Eurasian avian-like and 2009 pandemic H1N1 influenza viruses in mice and Guinea pigs. Sci Rep. 2016;6(1):27067. https://doi.org/10. 1038/srep27067.

39. Wan H, Sorrell EM, Song H, et al. Replication and transmission of H9N2 influenza viruses in ferrets: evaluation of pandemic potential. Baylis M, ed. PLoS One. 2008;3(8):e2923. doi:https://doi. org/10.1371/journal.pone.0002923.

40. Li X, Shi J, Guo J, Deng G, Zhang Q, Wang J, et al. Genetics, receptor binding property, and transmissibility in mammals of naturally isolated H9N2 avian influenza viruses. PLoS Pathog. 2014;10(11):e1004508. https://doi.org/10.1371/journal.ppat. 1004508

41. Stevens J, Blixt O, Chen LM, Donis RO, Paulson JC, Wilson IA. Recent avian $\mathrm{H} 5 \mathrm{~N} 1$ viruses exhibit increased propensity for acquiring human receptor specificity. J Mol Biol. 2008;381(5): 1382-94. https://doi.org/10.1016/j.jmb.2008.04.016.

42. Xiong X, Xiao H, Martin SR, et al. Enhanced human receptor binding by H5 haemagglutinins. Virology. 2014;456-457(1): 179-87. https://doi.org/10.1016/j.virol.2014.03.008.

43. Belser JA, Blixt O, Chen L-M, Pappas C, Maines TR, van Hoeven $\mathrm{N}$, et al. Contemporary north American influenza $\mathrm{H} 7$ viruses possess human receptor specificity: implications for virus transmissibility. Proc Natl Acad Sci U S A. 2008;105(21):7558-63. https:// doi.org/10.1073/pnas.0801259105.

44. de Wit E, Munster VJ, van Riel D, Beyer WEP, Rimmelzwaan GF, Kuiken T, et al. Molecular determinants of adaptation of highly pathogenic avian influenza H7N7 viruses to efficient replication in the human host. J Virol. 2010;84(3):1597-606. https://doi.org/10. 1128/JVI.01783-09.

45. Kilander A, Rykkvin R, Dudman SG, Hungnes O. Observed association between the HA1 mutation D222G in the 2009 pandemic influenza $\mathrm{A}(\mathrm{H} 1 \mathrm{~N} 1)$ virus and severe clinical outcome, Norway 2009-2010. Eur Secur. 2010;15(9):6-8.

46. Chutinimitkul S, Herfst S, Steel J, Lowen AC, Ye J, van Riel D, et al. Virulence-associated substitution D222G in the hemagglutinin of 2009 pandemic influenza A(H1N1) virus affects receptor binding. J Virol. 2010;84(22):11802-13. https://doi.org/10.1128/JVI. 01136-10.

47. Ramos I, Krammer F, Hai R, Aguilera D, Bernal-Rubio D, Steel J, et al. H7N9 influenza viruses interact preferentially with $\alpha 2,3-$ linked sialic acids and bind weakly to $\alpha 2,6$-linked sialic acids. J Gen Virol. 2013;94(Pt 11):2417-23. https://doi.org/10.1099/vir.0. 056184-0.

48. Belser JA, Gustin KM, Pearce MB, Maines TR, Zeng H, Pappas $\mathrm{C}$, et al. Pathogenesis and transmission of avian influenza A (H7N9) virus in ferrets and mice. Nature. 2013;501(7468):5569. https://doi.org/10.1038/nature12391.

49. Xiong X, Martin SR, Haire LF, Wharton SA, Daniels RS, Bennett MS, et al. Receptor binding by an H7N9 influenza virus from humans. Nature. 2013;499(7459):496-9. https://doi.org/10.1038/ nature12372.

50. Dortmans JC, Dekkers J, Wickramasinghe IN, et al. Adaptation of novel H7N9 influenza A virus to human receptors. Sci Rep. 2013;3(1):3058. https://doi.org/10.1038/srep03058.

51. Shi Y, Zhang W, Wang F, Qi J, Wu Y, Song H, et al. Structures and receptor binding of hemagglutinins from human-infecting H7N9 influenza viruses. Science. 2013;342(6155):243-7. https://doi. org/10.1126/science. 1242917 .
52. Tharakaraman K, Jayaraman A, Raman R, Viswanathan K, Stebbins NW, Johnson D, et al. Glycan receptor binding of the influenza A virus H7N9 hemagglutinin. Cell. 2013;153(7):148693. https://doi.org/10.1016/j.cell.2013.05.034.

53. Xu R, de Vries RP, Zhu X, Nycholat CM, McBride R, Yu W, et al. Preferential recognition of avian-like receptors in human influenza A H7N9 viruses. Science. 2013;342(6163):1230-5. https://doi. org/10.1126/science.1243761.

54. Zhou J, Wang D, Gao R, Zhao B, Song J, Qi X, et al. Biological features of novel avian influenza A (H7N9) virus. Nature. 2013;499(7459):500-3. https://doi.org/10.1038/nature12379.

55. Wang M, Zhang W, Qi J, Wang F, Zhou J, Bi Y, et al. Structural basis for preferential avian receptor binding by the humaninfecting H10N8 avian influenza virus. Nat Commun. 2015;6: 5600. https://doi.org/10.1038/ncomms6600.

56. Sun X, Jayaraman A, Maniprasad P, Raman R, Houser KV, Pappas C, et al. N-Linked glycosylation of the hemagglutinin protein influences virulence and antigenicity of the 1918 pandemic and seasonal H1N1 influenza a viruses. J Virol. 2013;87(15): 8756-66. https://doi.org/10.1128/JVI.00593-13.

57. Zhang Y, Zhu J, Li Y, et al. Glycosylation on hemagglutinin affects the virulence and pathogenicity of pandemic $\mathrm{H} 1 \mathrm{N1} / 2009$ influenza A virus in mice. Tang JW, ed. PLoS One. 2013;8(4):e61397. doi:https://doi.org/10.1371/journal.pone.0061397.

58. Hatta M. Molecular basis for high virulence of Hong Kong H5N1 influenza A viruses. Science. 2001;293(5536):1840-2. https://doi. org/10.1126/science.1062882.

59. Schrauwen EJA, Herfst S, Leijten LM, van Run P, Bestebroer TM, Linster M, et al. The multibasic cleavage site in $\mathrm{H} 5 \mathrm{~N} 1$ virus is critical for systemic spread along the olfactory and hematogenous routes in ferrets. J Virol. 2012;86(7):3975-84. https://doi.org/10. 1128/JVI.06828-11.

60. Suguitan AL, Matsuoka Y, Lau Y-F, Santos CP, Vogel L, Cheng LI, et al. The multibasic cleavage site of the hemagglutinin of highly pathogenic a/Vietnam/1203/2004 (H5N1) avian influenza virus acts as a virulence factor in a host-specific manner in mammals. J Virol. 2012;86(5):2706-14. https://doi.org/10.1128/JVI. 05546-11.

61. Schrauwen EJA, Bestebroer TM, Munster VJ, de Wit E, Herfst S, Rimmelzwaan GF, et al. Insertion of a multibasic cleavage site in the haemagglutinin of human influenza H3N2 virus does not increase pathogenicity in ferrets. J Gen Virol. 2011;92(Pt 6):1410-5. https://doi.org/10.1099/vir.0.030379-0.

62. Ji Y, White YJ, Hadden JA, Grant OC, Woods RJ. New insights into influenza A specificity: an evolution of paradigms. Curr Opin Struct Biol. 2017;44:219-31. https://doi.org/10.1016/j.sbi.2017.06.001.

63. Wagner R, Matrosovich M, Klenk H-D. Functional balance between haemagglutinin and neuraminidase in influenza virus infections. Rev Med Virol. 2002;12(3):159-66. https://doi.org/10. 1002/rmv.352.

64. Matsuoka Y, Swayne DE, Thomas C, Rameix-Welti MA, Naffakh $\mathrm{N}$, Warnes $\mathrm{C}$, et al. Neuraminidase stalk length and additional glycosylation of the hemagglutinin influence the virulence of influenza H5N1 viruses for mice. J Virol. 2009;83(9):4704-8. https://doi.org/10.1128/JVI.01987-08.

65. Hoffmann TW, Munier S, Larcher T, Soubieux D, Ledevin M, Esnault E, et al. Length variations in the NA stalk of an $\mathrm{H} 7 \mathrm{~N} 1$ influenza virus have opposite effects on viral excretion in chickens and ducks. J Virol. 2012;86(1):584-8. https://doi.org/10.1128/ JVI.05474-11.

66. Zhou H, Yu Z, Hu Y, et al. The special neuraminidase stalk-motif responsible for increased virulence and pathogenesis of $\mathrm{H} 5 \mathrm{~N} 1$ influenza A virus. Martin DP, ed. PLoS One. 2009;4(7):e6277. doi:https://doi.org/10.1371/journal.pone.0006277. 
67. Wang D, Yang L, Gao R, et al. Genetic tuning of the novel avian influenza $\mathrm{A}(\mathrm{H} 7 \mathrm{~N} 9)$ virus during interspecies transmission, China, 2013. Euro Surveill. 2014;19(25).

68. Fouchier RA, Schneeberger PM, Rozendaal FW, et al. Avian influenza A virus (H7N7) associated with human conjunctivitis and a fatal case of acute respiratory distress syndrome. Proc Natl Acad Sci U S A. 2004;101(5):1356-61. https://doi.org/10.1073/pnas. 0308352100.

69. Blumenkrantz D, Roberts KL, Shelton H, Lycett S, Barclay WS. The short stalk length of highly pathogenic avian influenza H5N1 virus neuraminidase limits transmission of pandemic $\mathrm{H} 1 \mathrm{~N} 1$ virus in ferrets. J Virol. 2013;87(19):10539-51. https://doi.org/10.1128/ JVI.00967-13.

70. Kawaoka Y, Krauss S, Webster RG. Avian-to-human transmission of the PB1 gene of influenza A viruses in the 1957 and 1968 pandemics. J Virol. 1989;63(11):4603-8.

71. Ito T, Couceiro JN, Kelm S, Baum LG, Krauss S, Castrucci MR, et al. Molecular basis for the generation in pigs of influenza A viruses with pandemic potential. J Virol. 1998;72(9):7367-73.

72. Makarova NV, Ozaki H, Kida H, Webster RG, Perez DR. Replication and transmission of influenza viruses in Japanese quail. Virology. 2003;310(1):8-15.

73. Hossain MJ, Hickman D, Perez DR. Evidence of expanded host range and mammalian-associated genetic changes in a duck H9N2 influenza virus following adaptation in quail and chickens. Montgomery JM, ed. PLoS One. 2008;3(9):e3170. doi:https:// doi.org/10.1371/journal.pone.0003170.

74. Giannecchini S, Clausi V, Di Trani L, et al. Molecular adaptation of an $\mathrm{H} 7 \mathrm{~N} 3$ wild duck influenza virus following experimental multiple passages in quail and turkey. Virology. 2010;408(2): 167-73. https://doi.org/10.1016/j.virol.2010.09.011.

75. Yamada S, Shinya K, Takada A, Ito T, Suzuki T, Suzuki Y, et al. Adaptation of a duck influenza A virus in quail. J Virol. 2012;86(3):1411-20. https://doi.org/10.1128/JVI.06100-11.

76. Thontiravong A, Kitikoon P, Wannaratana S, Tantilertcharoen R, Tuanudom R, Pakpinyo $\mathrm{S}$, et al. Quail as a potential mixing vessel for the generation of new reassortant influenza A viruses. Vet Microbiol. 2012;160(3-4):305-13. https://doi.org/10.1016/j. vetmic. 2012.05.043

77. Naffakh N, Tomoiu A, Rameix-Welti M-A, van der Werf S. Host restriction of avian influenza viruses at the level of the ribonucleoproteins. Annu Rev Microbiol. 2008;62(1):403-24. https://doi. org/10.1146/annurev.micro.62.081307.162746.

78. Freidl GS, Meijer A, de Bruin E, et al. Influenza at the animalhuman interface: a review of the literature for virological evidence of human infection with swine or avian influenza viruses other than A(H5N1). Euro Surveill. 2014;19(18).

79. Scholtissek C, Stech J, Krauss S, Webster RG. Cooperation between the hemagglutinin of avian viruses and the matrix protein of human influenza A viruses. J Virol. 2002;76(4):1781-6.

80. Murphy BR, Buckler-White AJ, London WT, Harper J, Tierney EL, Miller NT, et al. Avian-human reassortant influenza A viruses derived by mating avian and human influenza A viruses. J Infect Dis. 1984;150(6):841-50.

81. Imai M, Watanabe T, Hatta M, Das SC, Ozawa M, Shinya K, et al. Experimental adaptation of an influenza H5 HA confers respiratory droplet transmission to a reassortant $\mathrm{H} 5 \mathrm{HA} / \mathrm{H} 1 \mathrm{~N} 1$ virus in ferrets. Nature. 2012;486(7403):420-8. https://doi.org/10.1038/ nature10831.

82. Herfst S, Schrauwen EJA, Linster M, et al. Airborne transmission of influenza A/H5N1 virus between ferrets. Science (80). 2012;336(6088):1534-41. https://doi.org/10.1126/science. 1213362 .

83. Linster M, van Boheemen S, de Graaf M, Schrauwen EJA, Lexmond P, Mänz B, et al. Identification, characterization, and natural selection of mutations driving airborne transmission of
A/H5N1 virus. Cell. 2014;157(2):329-39. https://doi.org/10. 1016/j.cell.2014.02.040.

84. Zhu X, Viswanathan K, Raman R, Yu W, Sasisekharan R, Wilson IA. Structural basis for a switch in receptor binding specificity of two H5N1 hemagglutinin mutants. Cell Rep. 2015;13(8):168391. https://doi.org/10.1016/j.celrep.2015.10.027.

85. Gabriel G, Klingel K, Otte A, Thiele S, Hudjetz B, Arman-Kalcek $\mathrm{G}$, et al. Differential use of importin- $\alpha$ isoforms governs cell tropism and host adaptation of influenza virus. Nat Commun. 2011;2(1):156. https://doi.org/10.1038/ncomms1158.

86. Mehle A, Doudna JA. Adaptive strategies of the influenza virus polymerase for replication in humans. Proc Natl Acad Sci U S A. 2009;106(50):21312-6. https://doi.org/10.1073/pnas. 0911915106.

87. Gabriel G, Herwig A, Klenk H-D. Interaction of polymerase subunit PB2 and NP with importin alpha1 is a determinant of host range of influenza A virus. PLoS Pathog. 2008;4(2):e11. https:// doi.org/10.1371/journal.ppat.0040011.

88. Le QM, Sakai-Tagawa Y, Ozawa M, Ito M, Kawaoka Y. Selection of H5N1 influenza virus PB2 during replication in humans. J Virol. 2009;83(10):5278-81. https://doi.org/10. 1128/JVI.00063-09.

89. Manz B, Schwemmle M, Brunotte L. Adaptation of avian influenza A virus polymerase in mammals to overcome the host species barrier. J Virol. 2013;87(13):7200-9. https://doi.org/10.1128/JVI. 00980-13.

90. Nelson MI, Vincent AL, Kitikoon P, Holmes EC, Gramer MR. Evolution of novel reassortant a/H3N2 influenza viruses in North American swine and humans, 2009-2011. J Virol. 2012;86(16): 8872-8. https://doi.org/10.1128/JVI.00259-12.

91. Campbell PJ, Danzy S, Kyriakis CS, Deymier MJ, Lowen AC, Steel J. The M segment of the 2009 pandemic influenza virus confers increased neuraminidase activity, filamentous morphology, and efficient contact transmissibility to A/Puerto Rico/8/1934based reassortant viruses. J Virol. 2014;88(7):3802-14. https:// doi.org/10.1128/JVI.03607-13.

92. Campbell PJ, Kyriakis CS, Marshall N, Suppiah S, SeladiSchulman J, Danzy S, et al. Residue 41 of the Eurasian avianlike swine influenza a virus matrix protein modulates virion filament length and efficiency of contact transmission. J Virol. 2014;88(13):7569-77. https://doi.org/10.1128/JVI.00119-14.

93. Centers for Disease Control and Prevention. Media relationshave you heard? Archive: 2011. Available at https://www.cdc. gov/media/haveyouheard/stories/lab testingbigimg.html. Accessed January 5, 2018.

94. Claas EC, Osterhaus AD, van Beek R, et al. Human influenza A $\mathrm{H} 5 \mathrm{~N} 1$ virus related to a highly pathogenic avian influenza virus. Lancet. 1998;351(9101):472-7. https://doi.org/10.1016/S01406736(97)11212-0

95. Bender C, Hall H, Huang J, Klimov A, Cox N, Hay A, et al. Characterization of the surface proteins of influenza A (H5N1) viruses isolated from humans in 1997-1998. Virology. 1999;254(1):115-23. https://doi.org/10.1006/viro.1998.9529.

96. Peiris JS, Yu WC, Leung CW, Cheung CY, Ng WF, Nicholls JM, et al. Re-emergence of fatal human influenza A subtype H5N1 disease. Lancet. 2004;363(9409):617-9. https://doi.org/10.1016/ S0140-6736(04)15595-5.

97. World Health Organization. Influenza at the human-animal interface. Available at http://www.who.int/influenza/human_animal interface/Influenza_Summary_IRA_HA_interface_07_25_2017. pdf?ua $=1$. Accessed December 12, 2017.

98. World Health Organization. Cumulative number of confirmed human cases of avian influenza A(H5N1) reported to WHO. 2017. Available at http://www.who.int/influenza/human_animal_ interface/2017 1030 tableH5N1.pdf. Accessed December 14, 2017. 
99. Uyeki TM. Human infection with highly pathogenic avian influenza A (H5N1) virus: review of clinical issues. Clin Infect Dis. 2009;49(2):279-90. https://doi.org/10.1086/600035.

100. Chen Y, Liang W, Yang S, Wu N, Gao H, Sheng J, et al. Human infections with the emerging avian influenza A H7N9 virus from wet market poultry: clinical analysis and characterisation of viral genome. Lancet. 2013;381(9881):1916-25. https://doi.org/10. 1016/S0140-6736(13)60903-4.

101. World Health Organization Risk Assessment. Human infections with avian influenza A(H7N9) virus Summary of surveillance and investigation findings. 2014. Available at http://www.who.int/ influenza/human_animal_interface/RiskAssessment_H7N9 21Jan14.pdf. Accessed December 12, 2017.

102. Centers for Disease Control and Prevention. Summary of influenza Risk Assessment Tool (IRAT) Results. Available at https:// www.cdc.gov/flu/pandemic-resources/monitoring/irat-virussummaries.htm. Published 2017. Accessed December 12, 2017.

103. Yang ZF, Mok CK, Peiris JS, Zhong NS. Human infection with a novel avian influenza $\mathrm{A}(\mathrm{H} 5 \mathrm{~N} 6)$ virus. N Engl J Med. 2015;373(5):487-9. https://doi.org/10.1056/NEJMc1502983. This reference was the first to describe Human Infection with a novel Avian Influenza A(H5N6) virus.

104. World Health Organization. Human infections with avian influenza A(H5N6) virus - China. WHO 2016. Available at http://www. who.int/csr/don/07-december-2016-ah5n6-china/en/. Accessed December 12, 2017.

105. Peiris M, Yuen KY, Leung CW, Chan KH, Ip PLS, Lai RWM, et al. Human infection with influenza H9N2. Lancet. 1999;354(9182):916-7. https://doi.org/10.1016/S0140-6736(99) 03311-5.

106. Koopmans M, Wilbrink B, Conyn M, Natrop G, van der Nat H, Vennema H, et al. Transmission of H7N7 avian influenza A virus to human beings during a large outbreak in commercial poultry farms in the Netherlands. Lancet. 2004;363(9409):587-93. https:// doi.org/10.1016/S0140-6736(04)15589-X.

107. Wei SH, Yang JR, Wu HS, Chang MC, Lin JS, Lin CY, et al. Human infection with avian influenza A H6N1 virus: an epidemiological analysis. Lancet Respir Med. 2013;1(10):771-8. https:// doi.org/10.1016/S2213-2600(13)70221-2.

108. World Health Organization Western Pacific Region. Avian influenza A (H10N8). WPRO 2017. Available at http://www.wpro. who.int/china/mediacentre/factsheets/h10n $8 / \mathrm{en} /$. Accessed December 12, 2017.

109. Glezen WP. Emerging infections: pandemic influenza. Epidemiol Rev. 1996;18(1):64-76. https://doi.org/10.1093/oxfordjournals. epirev.a017917.

110. Kilbourne ED. Influenza pandemics of the 20th century. Emerg Infect Dis. 2006;12(1):9-14. https://doi.org/10.3201/eid1201. 051254.

111. Ran Z, Shen H, Lang Y, Kolb EA, Turan N, Zhu L, et al. Domestic pigs are susceptible to infection with influenza B viruses. J Virol. 2015;89(9):4818-26. https://doi.org/10.1128/JVI.00059-15.

112. Brockwell-Staats C, Webster RG, Webby RJ. Diversity of influenza viruses in swine and the emergence of a novel human pandemic influenza A (H1N1). Influenza Other Respir Viruses. 2009;3(5): 207-13. https://doi.org/10.1111/j.1750-2659.2009.00096.x.

113. Rewar S, Mirdha D, Rewar P. Treatment and prevention of pandemic H1N1 influenza. Ann Glob Heal. 2015;81(5):645-53. $\mathrm{https} / / /$ doi.org/10.1016/j.aogh.2015.08.014. This reference is a good resource for information regarding the treatment and prevention of pandemic H1N1 influenza.

114. Myers KP, Olsen CW, Gray GC. Cases of swine influenza in humans: a review of the literature. Clin Infect Dis. 2007;44(8): 1084-8. https://doi.org/10.1086/512813.

115. Shope RE. Swine influenza: i. Experimental transmission and pathology. J Exp Med. 1931;54(3):349-59. http://www.ncbi.nlm. nih.gov/pubmed/19869922. Accessed December 10, 2017

116. Smith TF, Burgert EO, Dowdle WR, Noble GR, Campbell RJ, Van Scoy RE. Isolation of swine influenza virus from autopsy lung tissue of man. N Engl J Med. 1976;294(13):708-10. https://doi. org/10.1056/NEJM197603252941308.

117. Zimmer SM, Burke DS. Historical perspective - emergence of influenza a (H1N1) viruses. N Engl J Med. 2009;361(3):279-85. https://doi.org/10.1056/NEJMra0904322.

118. Vincent AL, Awada L, Brown I, Chen H, Claes F, Dauphin G, et al. Review of influenza a virus in swine worldwide: a call for increased surveillance and research. Zoonoses Public Health. 2014;61(1):4-17. https://doi.org/10.1111/zph.12049.

119. Shinde V, Bridges CB, Uyeki TM, Shu B, Balish A, Xu X, et al. Triple-Reassortant swine influenza A (H1) in humans in the United States, 2005-2009. N Engl J Med. 2009;360(25):261625. https://doi.org/10.1056/NEJMoa0903812.

120. Cheng VC, To KK, Tse H, Hung IF, Yuen KY. Two years after pandemic influenza a/2009/H1N1: what have we learned? Clin Microbiol Rev. 2012;25(2):223-63. https://doi.org/10.1128/ CMR.05012-11.

121.• Bui CM, Chughtai AA, Adam DC, MacIntyre CR. An overview of the epidemiology and emergence of influenza A infection in humans over time. Arch Public Heal. 2017;75(1):15. https://doi. org/10.1186/s13690-017-0182-z. This reference describes the the epidemiology and emergence of influenza $A$ infection in humans over time.

122. Shrestha SS, Swerdlow DL, Borse RH, et al. Estimating the burden of 2009 pandemic influenza A (H1N1) in the United States (April 2009-April 2010). Clin Infect Dis. 2011;52(Supplement 1): S75-82. https://doi.org/10.1093/cid/ciq012.

123. Lindstrom S, Garten R, Balish A, Shu B, Emery S, Berman LS, et al. Human infections with novel reassortant influenza $\mathrm{A}(\mathrm{H} 3 \mathrm{~N} 2) \mathrm{V}$ viruses, United States, 2011. Emerg Infect Dis. 2012;18(5):834-7. https://doi.org/10.3201/eid1805.111922.

124. Centers for Disease Control and Prevention (National Center for Immunization and Respiratory Diseases). Case Count: Detected U.S. Human Infections with H3N2v by State since August 2011. Swine/Variant Influenza (Flu). Available at https://www.cdc.gov/ flu/swineflu/h3n2v-case-count.htm. Published 2017. Accessed December 13, 2017.

125. Komadina N, McVernon J, Hall R, Leder K. A historical perspective of influenza a(H1N2) virus. Emerg Infect Dis. 2014;20(1):612. https://doi.org/10.3201/eid2001.121848. 